\title{
Peran Sektor Pertanian dalam Pembangunan Ekonomi di Provinsi Jawa Timur (Pendekatan Input-Output)
}

\section{The Role of Agricultural Sector on Economic Development in East Java Province (Input-Output Approach)}

\author{
Henita Fajar Oktavia ${ }^{{ }^{*}}$, Nuhfil Hanani ${ }^{2}$, Suhartini ${ }^{2}$ \\ ${ }^{1}$ Pascasarjana Fakultas Pertanian, Universitas Brawijaya \\ ${ }^{2}$ Jurusan Sosial Ekonomi, Fakultas Pertanian, Universitas Brawijaya, Jl. Veteran Malang 65145, \\ Jawa Timur, Indonesia.
}

Diterima: 19 Agustus 2016; Direvisi: 29 Agustus 2016; Disetujui: 5 September 2016

\begin{abstract}
ABSTRAK
Tujuan pada penelitian ini adalah untuk melihat peran sektor pertanian dalam pembangunan ekonomi Provinsi Jawa Timur, dengan cara: 1). Menganalisis besarnya nilai struktur output, struktur nilai tambah bruto, struktur pendapatan, struktur tenaga kerja, angka pengganda output, angka pengganda pendapatan, angka pengganda nilai tambah bruto, angka pengganda tenaga kerja, backward linkage dan forward linkage; 2). Mengidentifikasi komoditas pertanian unggulan di Provinsi Jawa Timur. Metode Analisis menggunakan analisis Input-Output dengan data Input-Output Provinsi Jawa Timur tahun 2010 (110 sektor) yang di updating dan diagregasi menjadi Input-Output Provinsi Jawa Timur tahun 2013 (43 sektor). Hasil penelitian menunjukkan bahwa: 1). Kontribusi sektor pertanian dilihat dari: A). Struktur output yang dihasilkan sebesar 183.558.716,28 juta; B). Struktur nilai tambah bruto adalah 169.426.431,70 juta; C). Struktur pendapatan adalah 50.078.445,51 juta; D). Struktur tenaga kerja adalah 36.071.090 juta orang; E). Angka pengganda output dengan nilai terbesar berada pada komoditas ternak lainnya (2,35); F) Angka pengganda pendapatan dengan nilai terbesar berada pada komoditas telur (3,51); G) Angka pengganda nilai tambah bruto dengan nilai terbesar berada pada komoditas ternak lainnya $(2,54) ; \mathrm{H})$. Angka pengganda tenaga kerja dengan nilai terbesar berada pada komoditas padi $(2,12)$; I). Keterkaitan ke belakang dengan nilai terbesar berada pada komoditas ternak lainnya $(1,46)$; J). Keterkaitan ke depan dengan nilai terbesar berada pada komoditas padi (1,48). 2). Komoditas unggulan sektor pertanian, yaitu: komoditas ikan laut dan hasil perikanan lainnya, komoditas ikan darat dan hasil perikanan lainnya, komoditas padi, komoditas jagung, komoditas sayur-sayuran, komoditas buah-buahan, komoditas kedelai, komoditas telur, komoditas sapi, komoditas ayam, komoditas susu segar, komoditas ternak lainnya, komoditas domba dan kambing, komoditas tebu, komoditas tembakau.
\end{abstract}

Kata Kunci: sektor pertanian; input-output

\section{ABSTRACT}

The purposes of this research are: 1). Analysing the value of output structure, value added structure, income structure, labour structure, output multiplier, income multiplier, value added multiplier, labour multiplier, backward linkage and forward linkage.; 2). Identifying agricultural leading commodities in East Java province. Analysis method use Input-Output analysis with Input-Output data of East Java Province in 2010 (110 sectors) which updated and aggregated into Input-Output of East Java Province in 2013 (43 sectors). The results showed that: 1). Seen from the agricultural sector contribution: A). The result of output structure is 183.558.716,28 million; B). Value added structure is 169.426.431,70 million; C). Income structure is 50.078.445,51 million; D). Labor structure is 36.071 .090 million; E). Output multiplier created with the greatest value is the other livestock commodities (2,35); F) Income multiplier created with the greatest value is egg commodities (3,51); G) Value added created with the greatest value is the other livestock commodities (2,54); H). Labour multiplier created with the greatest value is paddy commodities (2,12); I). Backward linkage created with the greatest value is the other livestock commodities (1,46); J). Forward linkage created with the greatest value is paddy commodities $(1,48) .2)$. Leading commodities in agricultural sector are: marine fish and other fishery products, ground fish and other fishery products, paddy, corn, vegetables, fruits, soybean, egg, cow, chicken, milk, other livestock, sheep and goat, sugar cane, tobacco.

Keywords: agricultural sector; input-output

http://www.habitat.ub.ac.id, ISSN: 0853-5167 (p); 2338-2007 (e) 


\section{Pendahuluan}

Sensus pertanian tahun 2013, menjelaskan dalam lima tahun terakhir (tahun 2009 hingga tahun 2013) kontribusi sektor pertanian pada pembentukan PDRB Jawa Timur cenderung mengalami pelemahan $(16,34 \%$ menjadi $14,91 \%$ dan diiringi pelemahan tenaga kerja dari $42,93 \%$ menjadi $37,41 \%$ ). Oleh sebab itu, permasalahan yang sedang dialami sektor pertanian Jawa Timur, membuat sektor pertanian semakin hari tidak diminati dan membuat perannya terus menurun (Sensus Pertanian Jawa Timur, 2014).

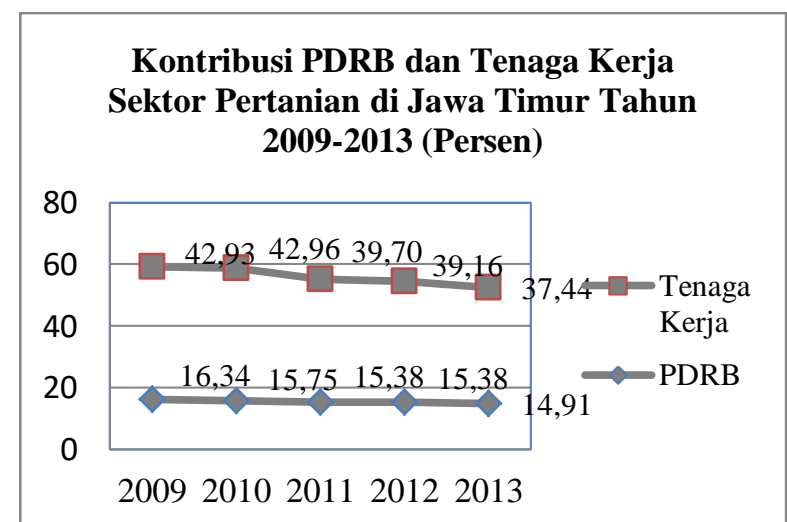

Gambar 1. Kontribusi PDRB dan Tenaga Kerja

Sektor Pertanian di Jawa Timur Tahun 2009-2013 (Persen) (BPS Provinsi Jawa Timur dalam Sensus Pertanian, 2014)

Besarnya peran sektor pertanian yang diberikan untuk pembangunan ekonomi, membuat sektor pertanian harus terus dikembangkan oleh pemerintah, namun di sisi lain peran sektor pertanian pun telah terjadi penurunan. Hal ini disampaikan oleh Arifin (2001) yang menjelaskan bahwa penyebab utama terjadinya penurunan peran sektor pertanian adalah pertumbuhan produksi pertanian yang masih terlalu berbasis pada ketersediaan lahan, padahal ada beberapa kegiatan ekonomi yang disertai konversi lahan pertanian yang menjadi kegunaan lain masih terus berlangsung. Tidak hanya itu saja, kondisi sektor pertanian sekarang pun sedang mengalami gejala penerimaan output yang terus berkurang dikarenakan alokasi dan kombinasi dari faktor produksi pertanian yang digunakan masih dikatakan belum mampu untuk mengimbangi penurunan yang sedang terjadi.

Pemerintah Jawa Timur melalui Bappeda Provinsi Jawa Timur (2013), membuat kebijakan revitalisasi pertanian dan pengembangan agroindustri atau agrobisnis di Jawa Timur, yaitu: peningkatan produktivitas, produksi, daya saing dan nilai tambah produk pertanian dan perikanan.
Kebijakan tersebut dibuat untuk fokus melakukan pengembangan pada sektor pertanian dengan berpijak pada konsep efisiensi. Diartikan pada efisiensi pengembangan sumberdaya pertanian yang dapat ditempuh dengan mengembangkan komoditas yang mempunyai keunggulan komperatif dalam aspek biofisik (lokasi, lahan) dan aspek sosial ekonomi (penguasaan teknologi, kemampuan sumberdaya manusia infrastruktur dicontohkan seperti pasar dan kebiasaan petani di masing-masing daerah) (Anonymous, 1995 dalam Syafa'at dan Friyatno, 2000).

Oleh sebab itu pertumbuhan ekonomi yang didukung oleh adanya komoditas unggulan dapat dijadikan potensi bagi pembangunan masyarakat daerah tersebut. Hal ini diperjelas oleh Taufik dan Saleh (2002) dalam Yulianita (2009), bahwa komoditas unggulan memberikan dua sumbangan berupa efek langsung yang mampu membuat kenaikan pada pendapatan faktor-faktor produksi daerah dan pendapatan daerah juga bagi produksi industri lokal dimana akan menghasilkan permintaan yang membantu industri lokal untuk terus tumbuh.

Tujuan pada penelitian ini adalah: 1). Menganalisis besarnya nilai struktur output, struktur nilai tambah bruto, struktur pendapatan, struktur tenaga kerja, angka pengganda output, angka pengganda pendapatan, angka pengganda nilai tambah bruto, angka pengganda tenaga kerja, backward linkage dan forward linkage. Hal ini dilakukan guna membantu melihat peran sektor pertanian dalam pembangunan ekonomi di Provinsi Jawa Timur; 2). Mengidentifikasi komoditas pertanian unggulan di Provinsi Jawa Timur.

\section{Metode Penelitian}

Penentuan lokasi penelitian dilakukan secara sengaja, yaitu di Provinsi Jawa Timur. Pemilihan lokasi dilakukan dengan pertimbangan sektor pertanian Jawa Timur masih menjadi tiga sektor utama Jawa Timur setelah sektor perdagangan, hotel dan restauran juga sektor industri pengolahan (Bappeda Provinsi Jawa Timur, 2013). Data yang digunakan dalam penelitian ini adalah data sekunder yang telah dipublikasikan oleh Badan Pusat Statistik Jawa Timur. Data yang digunakan untuk membantu penelitian ini adalah: 1). Tabel input-output Provinsi Jawa Timur transaksi domestik atas dasar harga produsen tahun 2010; 2). Produk Domestik Regional Bruto (PDRB) Provinsi Jawa Timur 2013 menurut lapangan usaha dan 
penggunaan; dan 3). Data tenaga kerja Provinsi Jawa Timur tahun 2013.

Data penelitian dianalisis dengan analisis Input-Output. Pengolahan data menggunakan aplikasi Excel. Tabel input-output Jawa Timur dilakukan updating dengan alasan ketersediaan data yang digunakan untuk melakukan analisis.

Langkah awal untuk melakukan analisis input-output adalah membuat tabel input-output Jawa Timur 2013, dengan meng-updating tabel input-output Jawa Timur 2010. Langkahnya seperti berikut:

\subsection{Analisis Peran Sektor Pertanian Provinsi Jawa Timur}

\subsubsection{Agregasi Input Output 2010}

Pada tahap ini masih menggunakan data input output Jawa Timur 2010 dimana data yang digunakan adalah data tabel input output transaksi atas dasar harga produsen 2010 dengan 110 sektor. Agregasi 110 sektor (2010) menjadi 43 sektor (2010) dengan cara mengelompokkan sektor-sektor yang ingin digabungkan peneliti agar tercipta 43 sektor. Pada kuadran pertama yaitu input antara, nilai koefisien tetap menggunakan nilai dari tabel input output transaksi atas dasar harga produsen 2010 dengan 110 sektor dengan menggabungkan beberapa sektor agar menjadi 43 sektor; cara kedua beralih ke permintaan akhir pada kuadran kedua. Pada kuadran ini digabungkan lagi 110 sektor tersebut menjadi 43 sektor sesuai deskripsi sektor yang diinginkan peneliti; sedangkan pada input primer di kuadran tiga tetap menggunakan nilai dari input output transaksi atas dasar harga produsen 2010 dengan 110 sektor tanpa mengubahnya menjadi 43 sektor. Proses tersebut telah diselesaikan semua, maka akan didapatkan tabel input output 43 sektor tahun 2010 yang terbaru.

Tabel input output 43 sektor tahun 2010 yang terbaru didapatkan, beralih kepada kuadran dua pada permintaan akhir kode 309 dan kuadran tiga pada input primer kode 209, dimana nilai yang ada masih berasal dari tahun 2010 dan harus dirubah menjadi nilai tahun 2013 yang diinginkan peneliti. Hal ini dilakukan untuk mempermudah dalam melakukan updating tabel input output 43 sektor tahun 2010 yang terbaru menjadi tabel input output 43 sektor tahun 2013.

Cara mencari kode 309 (2013) dengan membuat ratio 309 (2010). Nilai tersebut diperoleh dari 309 (2010) dibagi dengan total 309 (2010) secara keseluruhan (kolom). Nilai 309 (2010) didapatkan dilanjutkan dengan mencari nilai 309 (2013) menggunakan nilai dari PDRB Penggunaan Jawa Timur tahun 2013 dikalikan dengan nilai dari ratio 309 (2010). Pencarian nilai dari kode 209 (2013) juga menggunakan cara yang sama, yang membedakan hanya pada pencarian 209 (2013) dimana menggunakan PDRB Atas Dasar Harga Berlaku Jawa Timur tahun 2013.

\subsubsection{Updating Tabel Input Output Jawa Timur Tahun 2013}

a. Membuat Koefisien Input Antara (Matriks A)

Memulai hasil updating input antara suatu sektor pada tahun 2013, dimulai dengan menentukan nilai dari koefisien. Penentuan nilai tersebut menggunakan data dari tabel inputoutput 2010. Berikut rumus dari pencarian koefisien:

$a_{i j=\frac{Z_{I J}}{X_{j}}}$

Dimana:

$\mathrm{a}_{\mathrm{ij}} \quad$ : koefisien input antara sektor pertanian

$\mathrm{Z}_{\mathrm{ij}} \quad$ : input antara pertanian tahun 2010

$X_{j} \quad$ : total nilai tambah bruto tahun 2010

i : sektor pertanian dalam bentuk baris

j $\quad$ : sektor pertanian dalam bentuk kolom

Dijelaskan dari rumus diatas, dapat digambarkan untuk pencarian koefisien input antara atau matriks A 43 sektor tahun 2010 dengan membagi nilai dari setiap sektor (kolom) dengan nilai 209 (2010). Koefisien input antara membantu dalam mencari nilai transaksi guna dimasukkan pada kuadran satu yaitu transaksi antara.

b. Mencari nilai transaksi. Nilai ini nantinya akan masuk pada kuadran satu menjadi nilai dari transaksi antara, didapatkan dengan cara membagi nilai dari matrik A (2010) sektor 1 (contoh sampai dengan sektor 43) (kolom) dengan nilai dari 209 (2013).

c. Mencari nilai dari kode 190 (2010 menjadi 2013) dengan menjumlahkan secara total dari setiap sektor (kolom) dari nilai transaksi (2013).

d. Mencari nilai dari kode 180 (2010 menjadi 2013) dengan menjumlahkan secara total dari setiap sektor (baris) dari nilai transaksi (2013).

e. Mengisi nilai dari kode 301, 302, 303, 304, 305, 306 tahun 2013 dilakukan dengan cara nilai dari 301, 302, 303, 304, 305 atau 306 tahun 2010 per sektor dibagi dengan 
nilai dari 309 (2010) dan dikalikan dengan 309 (2013). Cara ini berlaku untuk kode lainnya.

f. Nilai 309 (2013) diperoleh dari total keseluruhan dari nilai 301 sampai dengan 306 (secara baris), dan berlaku untuk semua sektor.

g. Nilai 310 (2013) didapatkan dengan menjumlahkan nilai dari 180 (2013) setiap sektor dengan nilai dari 309 (2013).

h. Mengisi nilai dari kode 200, 201, 202, 203, 204, 205 tahun 2013 dilakukan dengan cara nilai dari 200, 201, 202, 203, 204 atau 205 tahun 2010 per sektor dibagi dengan nilai dari 209 (2010) dan dikalikan dengan 209 (2013). Cara ini berlaku untuk kode lainnya.

i. Nilai dari kode $210 \quad$ (2013) dengan menjumlahkan 190 (2013) dengan 209 (2013) per sektor.

j. $\quad$ Nilai dari kode 211 didapatkan dari ratio 209 (2010) dikalikan dengan jumlah tenaga kerja Jawa Timur (2013).

Setelah semua data dicari, lalu digabungkan pada sebuah tabel sesuai dengan kodenya dari tabel input output. Maka, dari sinilah tercipta tabel input output Jawa Timur Tahun 2013.

Tujuan pertama dari penelitian ini adalah menganalisis peran sektor pertanian terhadap perekonomian Provinsi Jawa Timur dimana dianalisis secara deskriptif. Penjabaran secara deskriptif tersebut dilakukan dengan melihat secara langsung data yang ada pada tabel inputoutput Provinsi Jawa Timur tahun 2013 dengan klasifikasi 43 sektor (setelah di updating).

\subsection{Analisis Komoditas Unggulan Di Provinsi Jawa Timur}

Analisis komoditas unggulan di Provinsi Jawa Timur dilakukan untuk membantu peran sektor pertanian Jawa Timur yang digunakan untuk membantu menjawab tujuan ke dua penelitian.

\subsubsection{Struktur Output}

Diartikan sebagai nilai produksi barang atau jasa yang dihasilkan oleh sektor-sektor ekonomi di Provinsi Jawa Timur. Tabel inputoutput updating tahun 2013, struktur output terletak pada kode 600. Biasanya dilihat dalam bentuk berapa persen (\%) kontribusi terhadap perekonomian Jawa Timur, yang diperoleh dari nilai dari output kode 600 per sektor (kolom) dibagi dengan total keseluruhan nilai dari output kode 600 .

\subsubsection{Struktur Nilai Tambah Bruto}

Struktur nilai tambah bruto guna melihat balas jasa untuk faktor produksi yang tercipta dikarenakan adanya kegiatan produksi dilambangkan dengan kode 209. Biasanya dilihat dalam bentuk berapa persen (\%) kontribusi terhadap perekonomian Jawa Timur, yang diperoleh dari nilai tambah bruto kode 209 per sektor (kolom) dibagi dengan total keseluruhan nilai dari nilai tambah bruto kode 209 .

\subsubsection{Struktur Pendapatan}

Menggambarkan sumber dana atau pendapatan yang didapatkan rumah tangga untuk konsumsinya dilambangkan dengan kode 201. Biasanya dilihat dalam bentuk berapa persen (\%) kontribusi terhadap perekonomian Jawa Timur, yang diperoleh dari pendapatan kode 201 per sektor (kolom) dibagi dengan total keseluruhan nilai dari pendapatan kode 201 .

\subsubsection{Struktur Tenaga Kerja}

Melihat tenaga kerja yang mampu masuk ke dalam sektor-sektor ekonomi pada suatu wilayah yang dilihat pada kode 211. Pada pencarian struktur tenaga kerja ini harus menghitung produktivitas tenaga kerja, rasio upah dan koefisien tenaga kerja. Produktivitas tenaga kerja didapatkan dengan cara 209 (2013) dibagi dengan 211 (2013). Rasio upah diperoleh dengan nilai 201 (2013) dibagi dengan 211 (2013) dan untuk koefisien tenaga kerja sendiri pembagian dari output (kode 600) dan tenaga kerja (kode 211).

\subsubsection{Angka Pengganda Output}

Pada analisis ini bertujuan untuk melihat dampak perubahan permintaan akhir sektor pertanian di Provinsi Jawa Timur terhadap sektor lain yang di teliti, apakah muncul kenaikan permintaan akhir yang nantinya akan meningkatkan output produksi sektor pertanian di Provinsi Jawa Timur sendiri tetapi juga akan meningkatkan output sektor lain dalam perekonomian. Untuk mencarinya menggunakan rumus sebagai berikut:

$O_{i j=} \sum_{i}^{n} \alpha_{i j}$

Dimana:

$O_{i j} \quad$ : pengganda output sektor $j$.

$\alpha_{i j} \quad$ : elemen matriks kebalikan Leontief.

I : baris ke $1,2, \ldots . . \mathrm{n}$. 


\subsubsection{Angka Pengganda Pendapatan}

Analisis pengganda pendapatan adalah analisis yang digunakan untuk melihat pengaruh dari perubahan-perubahan yang muncul di permintaan akhir pada sektor pertanian yang diteliti terhadap pendapatan di sektor pertanian itu sendiri yang terjadi di Provinsi Jawa Timur. Angka pengganda pendapatan dihitung dengan rumus seperti berikut:

Income Multiplier Type $1=\frac{V(I-A)^{-1}}{V}$

Dimana:

V : bagian nilai tambah upah atau gaji per total output.

$(\mathrm{I}-\mathrm{A})^{-1}$ : matriks kebalikan leontif.

\subsubsection{Angka Pengganda Nilai Tambah Bruto}

Digunakan untuk mengukur peningkatan dari pendapatan yang diakibatkan oleh adanya perubahan output dalam perekonomian. Pendapatan pada analisis ini menggunakan upah dan gaji yang diterima oleh rumah tangga.

\section{Matriks Nilai Tambah Bruto \\ : Koefisien Nilai Tambah Bruto}

\subsubsection{Angka Pengganda Tenaga Kerja}

Analisis mencoba untuk menunjukkan efek total dari perubahan lapangan pekerjaan yang diakibatkan oleh adanya satu unit perubahan permintaan akhir di sektor pertanian. Analisis ini juga membantu untuk melihat peran sektor pertanian di Provinsi Jawa Timur dalam meningkatkan tenaga kerja yang terserap. Rumus perhitungan sebagai berikut:

Matriks Tenaga Kerja: Koefisien Tenaga Kerja

\subsubsection{Kaitan Ke Depan}

Pada analisis ini digunakan untuk melihat peningkatan output sektor pertanian di Provinsi Jawa Timur yang akan meningkatkan distribusi output untuk sektor pertanian sendiri, nantinya membuat sektor ekonomi lainnya memiliki input yang lebih banyak. Hal tersebut akan membuat sektor ekonomi lainnya akan terus meningkatkan proses produksinya sehingga akan menghasilkan output yang lebih banyak. Rumus perhitungan yang digunakan sebagai berikut:

$$
T F L_{i=\frac{\sum_{j=1}^{n} b_{i j}}{1 / n \sum_{i=1}^{n} \sum_{j=1}^{n} b_{i j}}}
$$

Dimana:

$T F L_{i} \quad$ : total Forward Linkage untuk sektor i.

$b_{i j} \quad$ : elemen matrik kebalikan Leontief baris ke i, kolom ke j.

n : jumlah sektor.

\section{Hasil dan Pembahasan}

\subsection{Peran Sektor Pertanian Dalam Pembangunan Ekonomi Di Provinsi Jawa Timur}

\section{a. Struktur Output}

Pada tabel 1 kontribusi sektor pertanian Jawa Timur terhadap output Jawa Timur kurang bersaing dengan sektor non pertanian lainnya dalam perekonomian.

Tabel 1. Lima Belas Sektor Tertinggi Pada Struktur Output Provinsi Jawa Timur

\begin{tabular}{ccccc}
\hline $\begin{array}{c}\text { Nama } \\
\text { Sektor }\end{array}$ & $\begin{array}{c}\text { Ko } \\
\text { de }\end{array}$ & $\begin{array}{c}\text { Output } \\
\text { (Juta Rupiah) }\end{array}$ & $\begin{array}{c}\text { Pe- } \\
\text { ringkat }\end{array}$ & $\begin{array}{c}\text { Kontribusi } \\
\text { Dalam } \\
\text { Perekonomian } \\
\text { Jawa Timur } \\
\text { (Persen) }\end{array}$ \\
\hline Padi & 01 & $38.028 .853,89$ & 9 & 2,33 \\
\hline $\begin{array}{c}\text { Ikan Darat } \\
\text { Dan Hasil } \\
\text { Perikanan } \\
\text { Lainnya }\end{array}$ & 32 & $27.604 .611,47$ & 10 & 1,69 \\
\hline Sapi & 20 & $18.704 .340,64$ & 11 & 1,14 \\
\hline Jagung & 02 & $17.609 .227,53$ & 12 & 1,08 \\
\hline $\begin{array}{c}\text { Ikan Laut } \\
\text { Dan Hasil }\end{array}$ & 33 & $15.021 .519,80$ & 14 & 0,92 \\
Perikanan & & & & \\
Laut & & & & \\
\hline $\begin{array}{c}\text { Tanaman } \\
\text { Pangan } \\
\text { Lainnya }\end{array}$ & 06 & $8.766 .329,51$ & 15 & 0,54 \\
\hline
\end{tabular}

Sektor pertanian mengalami penurunan dalam hal kontribusi dimana output yang mampu diciptakan hanya berada di peringkat 9 
(komoditas padi); 10 (komoditas ikan darat dan hasil perikanan lainnya); 11 (komoditas sapi); 12 (komoditas jagung); 14 (komoditas ikan laut dan hasil perikanan laut) dan 15 (tanaman pangan lainnya), namun demikian output sektor pertanian Jawa Timur masih membantu dan diperlukan sektor lain untuk menghasilkan output sektor non pertanian tersebut (Amir dan Riphat, 2005).

Dilihat secara menyeluruh sektor pertanian hanya menghasilkan output sebesar 183.558.716,28 juta rupiah atau berkontribusi sebesar 11,23 persen bagi perekonomian (33 sektor) dibandingkan dengan sektor non pertanian dimana menghasilkan output lebih tinggi sebesar 1.451.144.705,13 milyar rupiah atau berkontribusi sebesar 88,77 persen bagi perekonomian. Berfokus pada sektor pertanian, sub sektor pertanian yang memberikan kontribusi cukup penting bagi Jawa Timur ditempati oleh komoditas padi (2,33 persen); komoditas ikan darat dan hasil perikanan lainnya (1,69 persen); komoditas sapi (1,44 persen); dan komoditas jagung (1,08 persen).

\section{b. Struktur Nilai Tambah Bruto}

Kontribusi sektor pertanian yang ditampilkan pada Tabel 2, dapat dikatakan bahwa sektor pertanian masih menjadi sektor yang memiliki kontribusi rendah dimana pada beberapa sub sektor di sektor pertanian nilai struktur output yang diperoleh lebih rendah dari nilai struktur nilai tambah bruto (komoditas padi, komoditas jagung). Maka, dari distribusi nilai tambah antar sektor terlihat peranan sektor non pertanian dalam pembentukan struktur ekonomi wilayah Jawa Timur sangat besar sedangkan peranan sektor pertanian masih kecil. Dengan demikian pembangunan pertanian yang dilakukan di Jawa Timur masih belum memprioritaskan pada kemampuan sumberdaya alamnya sendiri, dimana pada akhirnya hal ini menjadi pemikiran tersendiri bagi pemerintah Jawa Timur adakah kemungkinan Jawa Timur tetap unggul pada sektor pertanian. Kondisi tersebut mengingatkan bahwa Jawa Timur disebut sebagai lumbung nasional dan berkedaulatan pangan (Syafa'at dan Friyatno, 2000; Sensus Pertanian Jawa Timur, 2014).

Hal tersebut dikarenakan untuk sektor
pertanian hanya 169.426.431,70 juta rupiah atau 15,88 persen (33 sektor) dibandingkan dengan sektor non pertanian 897.520.803,07 juta rupiah atau 84,12 persen. Maka, dilihat dari hasil analisis kontribusi nilai tambah bruto yang disumbangkan sub sektor pertanian Jawa Timur tidak jauh berbeda (dilihat dari komoditas) dengan output sektor pertanian yang disumbangkan kepada perekonomian Jawa Timur. Komoditas padi berkontribusi 3,76 persen; komoditas jagung dan sapi berkontribusi sebesar 1,65 persen dan komoditas ikan darat dan hasil perikanan lainnya berkontribusi sebesar 1,36 persen.

Tabel 2. Lima Belas Sektor Tertinggi Pada Struktur Nilai Tambah Bruto Provinsi Jawa Timur

\begin{tabular}{ccccc}
\hline $\begin{array}{c}\text { Nama } \\
\text { Sektor }\end{array}$ & $\begin{array}{c}\text { Ko- } \\
\text { de }\end{array}$ & $\begin{array}{c}\text { Nilai Tambah } \\
\text { Bruto } \\
\text { (Juta Rupiah) }\end{array}$ & $\begin{array}{c}\text { Pe- } \\
\text { ringkat }\end{array}$ & $\begin{array}{c}\text { Kontribusi } \\
\text { Dalam } \\
\text { Perekonomian } \\
\text { Jawa Timur } \\
\text { (Persen) }\end{array}$ \\
\hline Padi & 01 & $40.119 .188,77$ & 8 & 3,76 \\
\hline Jagung & 02 & $17.650 .798,00$ & 10 & 1,65 \\
\hline Sapi & 20 & $17.604 .326,32$ & 11 & 1,65 \\
\hline $\begin{array}{c}\text { Ikan Darat } \\
\text { Dan Hasil } \\
\text { Perikanan } \\
\text { Lainnya }\end{array}$ & 32 & $14.533 .783,37$ & 12 & 1,36 \\
\hline $\begin{array}{c}\text { Tanaman } \\
\text { Pangan }\end{array}$ & 06 & $9.342 .525,27$ & 14 & \\
Lainnya & & & & 0,88 \\
\hline $\begin{array}{c}\text { Sayur- } \\
\text { Sayuran }\end{array}$ & 07 & $7.910 .327,39$ & 15 & 0,74 \\
\hline
\end{tabular}

\section{c. Struktur Pendapatan}

Struktur pendapatan menggambarkan sumber dana atau pendapatan yang didapatkan rumah tangga untuk konsumsinya, dan untuk di Jawa Timur masih didominasi oleh sektor non pertanian. Tiga sektor utama tersebut, yaitu: 1). Sektor perdagangan, hotel dan restauran dengan kontribusi sebesar 23,55 persen; 2). Sektor keuangan dan jasa dengan kontribusi 19,66 persen; dan 3). Sektor konstruksi dengan pemberian kontribusi pada strktur pendapatan adalah 10,30 persen. Data tersebut menunjukkan bahwa peningkatan pendapatan bagi masyarakat lebih terasa dari sektor non pertanian. Kondisi ini menjadi tanda dari: 1). Adanya tekanan keterbatasan lahan dan kesempatan ekonomi di sektor pertanian dan pedesaan; 2). Adanya tekanan ekonomi pedesaan yang surplus tenaga kerja; dan 3). Munculnya tarikan guna memanfaatkan perbedaan upah yang ada di desa dan di luar desa (Tambunan, 2010).

Masih kecilnya kontribusi pendapatan di sektor pertanian (dimana dari 33 sektor pendapatan yang didapatkan hanya sebesar 50.078.445,51 juta rupiah atau berkontribusi sebesar 17,24 persen), mencerminkan bahwa 
kesejahteraan petani belumlah sempurna. Hal ini dikarenakan produktivitas dan upah buruh petani yang sangat rendah, walaupun demikian kurun waktu dua tahun terakhir (2012 dan 2013) kesejahteraan petani mulai tampak yang dicirikan dengan nilai tukar petani 2013 diatas 100. Selain itu, indeks yang diterima petani 2013 adalah 159,80 dan indeks yang dibayar petani 155,27. Data ini walaupun dikatakan tinggi dan petani tampak sejahtera, namun nyatanya jika pendapatan yang diterima petani belum bisa dimanfaatkan untuk memenuhi kebutuhan dasar masih tetap dikatakan belum sejahtera (Sensus Pertanian Jawa Timur, 2014) dan hal tersebut didukung dengan output yang dihasilkan oleh sektor pertanian juga rendah dibandingkan dengan output yang dihasilkan oleh sektor non pertanian.

Tabel 3. Lima Belas Sektor Tertinggi Pada Struktur Pendapatan Provinsi Jawa Timur

\begin{tabular}{ccccc}
\hline $\begin{array}{c}\text { Nama } \\
\text { Sektor }\end{array}$ & $\begin{array}{c}\text { Ko- } \\
\text { de }\end{array}$ & $\begin{array}{c}\text { Pendapatan } \\
\text { (Juta } \\
\text { Rupiah) }\end{array}$ & $\begin{array}{c}\text { Pe- } \\
\text { ringkat }\end{array}$ & $\begin{array}{c}\text { Kontribusi } \\
\text { Dalam } \\
\text { Perekonomi } \\
\text { an Jawa } \\
\text { Timur } \\
\text { (Persen) }\end{array}$ \\
\hline Padi & 01 & $12.843 .654,89$ & 8 & 4,42 \\
\hline Sapi & 20 & $9.319 .608,98$ & 9 & 3,21 \\
\hline $\begin{array}{c}\text { Ikan Darat } \\
\text { Dan Hasil } \\
\text { Perikanan } \\
\text { Lainnya }\end{array}$ & 32 & $4.281 .395,49$ & 10 & 1,47 \\
\hline $\begin{array}{c}\text { Jagung } \\
\text { Tanaman } \\
\text { Pangan } \\
\text { Lainnya }\end{array}$ & 02 & $4.047 .884,73$ & 11 & 1,39 \\
\hline $\begin{array}{c}\text { Buah- } \\
\text { Buahan }\end{array}$ & 08 & $2.413 .359,98$ & 13 & 1,17 \\
\hline $\begin{array}{l}\text { Ikan Laut } \\
\text { Dan Hasil } \\
\text { Perikanan } \\
\text { Laut }\end{array}$ & 33 & $2.052 .503,63$ & 15 & 0,71 \\
\hline & & & & \\
\hline & & & & \\
\hline & & & & \\
\hline & & & & \\
\hline
\end{tabular}

d. Struktur Tenaga Kerja

Berdasarkan Tabel 4 terlihat dari jumlah tenaga kerja dan kontribusinya pada perekonomian Jawa Timur, sektor pertanian (pada sub sektor perikanan, yaitu: ikan darat dan hasil perikanan lainnya juga ikan laut dan hasil perikanan laut; sub sektor peternakan dan hasil lain-lainnya, yaitu: sapi; sub sektor tanaman pangan, yaitu: padi, jagung; sub sektor kehutanan: jasa pertanian dan perkebunan, kayu jati; dan sub sektor perkebunan: tembakau, cengkeh dan tebu) mampu menyaingi sektor non pertanian yang masuk ke dalam lima belas sektor utama.

Tabel 4. Jumlah Tenaga Kerja Dan Rasio Upah Tenaga Kerja Di Jawa Timur Tahun 2013

\begin{tabular}{cccc}
\hline Sektor & $\begin{array}{c}\text { Ko- } \\
\text { De/ Pe- } \\
\text { Ringkat }\end{array}$ & $\begin{array}{c}\text { NTB } \\
\text { (Juta Rp) }\end{array}$ & $\begin{array}{c}\text { Jumlah } \\
\text { Tenaga Kerja } \\
\text { (Orang) }\end{array}$ \\
\hline $\mathbf{1}$ & $\mathbf{2}$ & $\mathbf{3}$ & $\mathbf{5}$ \\
\hline $\begin{array}{c}\text { Ikan Darat } \\
\text { Dan Hasil } \\
\text { Perikanan } \\
\text { Lainnya }\end{array}$ & $32 / 2$ & $14.533 .783,37$ & $4.895 .134,52$ \\
\hline Sapi & $20 / 3$ & $17.604 .326,32$ & $3.820 .138,34$ \\
\hline Padi & $1 / 4$ & $40.119 .188,77$ & $3.284 .693,56$ \\
\hline $\begin{array}{c}\text { Jasa } \\
\text { Pertanian } \\
\text { Dan }\end{array}$ & $28 / 6$ & $1,760,218.89$ & $2,767,652.90$ \\
Perkebunan & & & \\
\hline Kayu Jati & $29 / 7$ & $1,562,820.48$ & $2,457,276.56$ \\
\hline $\begin{array}{c}\text { Ikan Laut } \\
\text { Dan Hasil } \\
\text { Perikanan } \\
\text { Laut }\end{array}$ & $33 / 8$ & $6,885,419.97$ & $2,319,083.48$ \\
\hline Tembakau & $12 / 9$ & $6,373,495.40$ & $2,084,359.75$ \\
\hline Jagung & $02 / 11$ & $17,650,798.00$ & $1,445,130.48$ \\
\hline Cengkeh & $17 / 12$ & $4,346,332.38$ & $1,421,405.32$ \\
\hline Tebu & $11 / 14$ & $3,836,287.27$ & $1,254,602.42$ \\
\hline & & & \\
\hline
\end{tabular}

Berdasarkan Tabel 4 terlihat dari jumlah tenaga kerja dan kontribusinya pada perekonomian Jawa Timur, sektor pertanian (pada sub sektor perikanan, yaitu: ikan darat dan hasil perikanan lainnya juga ikan laut dan hasil perikanan laut; sub sektor peternakan dan hasil lain-lainnya, yaitu: sapi; sub sektor tanaman pangan, yaitu: padi, jagung; sub sektor kehutanan: jasa pertanian dan perkebunan, kayu jati; dan sub sektor perkebunan: tembakau, cengkeh dan tebu) mampu menyaingi sektor non pertanian yang masuk ke dalam lima belas sektor utama.

Masing-masing komoditas tersebut memberikan kontribusi bagi perekonomian Jawa Timur sebesar 2,36 persen (komoditas padi); 1,04 persen (komoditas jagung); 0,90 persen (komoditas tebu); 1,50 persen (komoditas tembakau); 1,02 persen (komoditas cengkeh); 2,75 persen (komoditas sapi); 1,99 persen (sub sektor kehutanan bagian jasa pertanian); 1,77 persen (komoditas kayu jati); 3,52 persen (komoditas ikan darat dan hasil perikanan 
lainnya); 1,67 persen (ikan laut dan hasil perikanan laut). Di sisi lain, komoditas pertanian lainnya masih belum sepenuhnya bisa bersaing dari jumlah tenaga kerja dan produktivitas tenaga kerja Hal ini menjadikan sektor pertanian diduga mengalami kekurangan tenaga kerja, dan mungkin saja telah terjadi perpindahan profesi ke sektor lainnya.

Tabel 5. Koefisien Tenaga Kerja Sektoral Jawa Timur Tahun 2013

\begin{tabular}{cccc}
\hline $\begin{array}{c}\text { Nama } \\
\text { Sektor }\end{array}$ & TK (Orang) & \multicolumn{2}{c}{$\begin{array}{c}\text { Koefisien Tenaga } \\
\text { Kerja }\end{array}$} \\
\cline { 3 - 4 } & & Nilai & Peringkat \\
\hline $\begin{array}{c}\text { Buah- } \\
\text { Buahan }\end{array}$ & $599,287.12$ & 13,52 & 10 \\
\hline $\begin{array}{c}\text { Sayur- } \\
\text { Sayuran }\end{array}$ & $647,645.24$ & 13,47 & 11 \\
\hline $\begin{array}{c}\text { Kacang } \\
\text { Tanah }\end{array}$ & $168,700.74$ & 12,29 & 12 \\
\hline Kedelai & $174,169.96$ & 12,25 & 13 \\
\hline Jagung & $1,445,130.48$ & 12,19 & 14 \\
\hline $\begin{array}{c}\text { Kacang } \\
\text { Hijau }\end{array}$ & $118,294.58$ & 11,93 & 15 \\
\hline
\end{tabular}

Pada sektor pertanian khususnya sub sektor tanaman pangan, yaitu: buah-buahan, sayur-sayuran, kacang tanah, kedelai, jagung dan kacang hijau hanya menempati peringkat 10 sampai dengan 15, dimana komoditas buahbuahan, sayur-sayuran, kacang tanah, kedelai, jagung dan kacang hijau memiliki daya serap cukup tinggi dibandingkan komoditas lainnya yang ada pada sektor pertanian. Komoditas buahbuahan, sayur-sayuran, kacang tanah, kedelai, jagung dan kacang hijau memiliki nilai koefisien sebesar 13,52;13,47;12,29;12,25; 12,19 dan 11,93 sehingga guna menghasilkan satu unit output pada komoditas tersebut senilai $\mathrm{Rp} 1$ membutuhkan tenaga kerja sebanyak 13 orang; 13 orang; 12 orang; 12 orang; 12 orang dan 11 orang.

\section{e. Angka Pengganda Output}

Berhubungan dengan peran sektor pertanian terhadap pembangunan ekonomi di Jawa Timur, jika dilihat dari data yang memiliki nilai angka pengganda terbesar adalah dari sub sektor peternakan (komoditas ternak lainnya, komoditas telur, komoditas domba dan kambing, komoditas susu segar, komoditas unggas lainnya dan komoditas ayam); sub sektor perikanan (komoditas ikan laut dan hasil perikanan laut) dan sub sektor perkebunan (komoditas tebu) dimana untuk sub sektor pertanian lainnya tidak berada di lima belas sektor utama dengan angka pengganda output terbesar.

Tabel 6.Pengganda Output Sektor Perekonomian Jawa Timur Tahun 2013

\begin{tabular}{cccc}
\hline Sektor & Kode & $\begin{array}{c}\text { Pengganda } \\
\text { Output }\end{array}$ & Peringkat \\
\hline $\begin{array}{c}\text { Ternak } \\
\text { Lainnya }\end{array}$ & 27 & 2,35 & 3 \\
\hline Telur & 26 & 2,17 & 6 \\
\hline $\begin{array}{c}\text { Domba } \\
\text { Dan } \\
\text { Kambing }\end{array}$ & 22 & 2,05 & 7 \\
\hline $\begin{array}{c}\text { Ikan Laut } \\
\text { Dan Hasil } \\
\text { Perikanan } \\
\text { Laut }\end{array}$ & 33 & 2,04 & 8 \\
\hline Susu Segar & 25 & 1,87 & 10 \\
\hline $\begin{array}{c}\text { Unggas } \\
\text { Lainnya }\end{array}$ & 24 & 1,86 & 11 \\
\hline Ayam & 23 & 1,85 & 12 \\
\hline Tebu & 11 & 1,58 & 15 \\
\hline
\end{tabular}

f. Angka Pengganda Pendapatan

Tabel 7. Angka Pengganda Pendapatan Sektor Perekonomian Jawa Timur Tahun 2013

\begin{tabular}{cccc}
\hline Sektor & Kode & $\begin{array}{c}\text { Pengganda } \\
\text { Pendapatan }\end{array}$ & Peringkat \\
\hline Telur & 26 & 3,51 & 3 \\
\hline Susu Segar & 25 & 2,77 & 6 \\
\hline Kacang Tanah & 04 & 2,66 & 7 \\
\hline Ayam & 23 & 2,34 & 8 \\
\hline $\begin{array}{c}\text { Ternak } \\
\text { Lainnya }\end{array}$ & 27 & 2,30 & 9 \\
\hline $\begin{array}{c}\text { Domba Dan } \\
\text { Kambing }\end{array}$ & 22 & 2,28 & 10 \\
\hline $\begin{array}{c}\text { Unggas } \\
\text { Lainnya }\end{array}$ & 24 & 2,14 & 13 \\
\hline Kedelai & 03 & 2,04 & 14 \\
\hline $\begin{array}{c}\text { Ikan Laut Dan } \\
\text { Hasil }\end{array}$ & 33 & 1,89 & 15 \\
Perikanan Laut & & & \\
\hline
\end{tabular}

Ditampilkan pada Tabel 7 diatas, bahwa sektor yang memiliki nilai pengganda pendapatan terbesar untuk sektor pertanian dari sub sektor peternakan dan hasil lain-lainnya (telur); dimana menyumbang pengganda pendapatan dengan nilai 3,51. Angka pengganda pendapatan pada sektor pertanian mengalami peningkatan dikarenakan sub sektor peternakan dan hasil lainlainnya (komoditas telur, komoditas susu segar, komoditas ayam, komoditas ternak lainnya, komoditas domba dan kambing, komoditas unggas lainnya); sub sektor tanaman pangan (komoditas kacang tanah, komoditas kedelai) dan sub sektor perikanan (komoditas ikan laut dan hasil perikanan laut) mampu bersaing dengan 
sektor non pertanian lainnya. Komoditas telur, komoditas susu segar, komoditas ayam, komoditas ternak lainnya, komoditas domba dan kambing, komoditas unggas lainnya, komoditas kacang tanah, komoditas kedelai dan komoditas ikan laut dan hasil perikanan laut menunjukkan jika terjadi peningkatan pada permintaan akhir sebesar 1 satuan maka akan meningkatkan pendapatan rumah tangga semua sektor sebesar 3,51 satuan; 2,77 satuan; 2,34 satuan; 2,30 satuan; 2,28 satuan; 2,14 satuan; 2,66 satuan; 2,04 satuan; dan 1,89 satuan. Pada sub-sub sektor pertanian lainnya masih menyumbang pengganda pendapatan yang kecil bagi perekonomian Jawa Timur, hal ini disebabkan oleh nilai upah dan gaji (kode 201) yang relatif kecil dibandingkan dengan jumlah output (kode 600) pada sektor tersebut (Amir dan Riphat, 2005).

\section{g. Angka Pengganda Nilai Tambah Bruto}

Tabel 8. Pengganda Nilai Tambah Bruto Sektor Perekonomian Jawa Timur Tahun 2013

\begin{tabular}{cccc}
\hline Sektor & Kode & $\begin{array}{c}\text { Pengganda } \\
\text { Nilai Tambah } \\
\text { Bruto }\end{array}$ & Peringkat \\
\hline $\begin{array}{c}\text { Ternak } \\
\text { Lainnya }\end{array}$ & 27 & 2,54 & 4 \\
\hline Telur & 26 & 2,25 & 6 \\
\hline $\begin{array}{c}\text { Domba Dan } \\
\text { Kambing }\end{array}$ & 22 & 2,09 & 7 \\
\hline $\begin{array}{c}\text { Ikan Laut } \\
\text { Dan Hasil } \\
\text { Perikanan } \\
\text { Laut }\end{array}$ & 33 & 2,05 & 8 \\
\hline Ayam & 23 & 1,91 & 10 \\
\hline Susu Segar & 25 & 1,84 & 11 \\
\hline $\begin{array}{c}\text { Unggas } \\
\text { Lainnya }\end{array}$ & 24 & 1,81 & 13 \\
\hline
\end{tabular}

Sub sektor peternakan dan hasil lainlainnya (komoditas ternak lainnya, komoditas telur, komoditas domba dan kambing, komoditas ayam, komoditas susu segar, komoditas unggas lainnya); dan sub sektor perikanan (komoditas ikan laut dan hasil perikanan laut) memiliki nilai pengganda masing-masing sebesar 2,54; 2,25; 2,$09 ; 1,91 ; 1,84 ; 1,81$ dan 2,05 . Hal tersebut dapat diartikan jika terjadi peningkatan permintaan akhir sebesar 1 unit uang akan meningkatan pengganda sub sektor-sub sektor yang khususnya berada pada sektor pertanian sebesar 2,54 unit; 2,25 unit; 2,09 unit; 1,91 unit; 1,84 unit; 1,81 unit dan 2,05 unit.

Hasil yang diperoleh pada analisis pengganda nilia tambah bruto, bahwa khususnya pada sektor pertanian yang dapat dijadikan komoditas unggulan adalah dari sub sektor peternakan dan hasil lain-lainnya (komoditas ternak lainnya, komoditas telur, komoditas domba dan kambing, komoditas ayam, komoditas susu segar, komoditas unggas lainnya); dan sub sektor perikanan (komoditas ikan laut dan hasil perikanan laut). Komoditas ini memiliki keterkaitan melalui konsumsi yang berasal dari nilai tambah yang diperoleh dari sub sektor yang ada pada sektor pertanian dan akan digunakan untuk membeli produk industri lain guna memenuhi kebutuhan konsumsi rumah tangga. Sehingga dapat disimpulkan bahwa dengan adanya keterkaitan konsumsi menjadikan munculnya permintaan produk yang akan dihasilkan oleh berbagai industri (Syafa'at dan Friyatno, 2000).

\section{h. Angka Pengganda Tenaga Kerja}

Tabel 9. Pengganda Tenaga Kerja Sektor Perekonomian Jawa Timur Tahun 2013

\begin{tabular}{cccc}
\hline Sektor & Kode & $\begin{array}{c}\text { Pengganda } \\
\text { Tenaga Kerja }\end{array}$ & Peringkat \\
\hline Padi & 01 & 2,12 & 10 \\
\hline Kedelai & 03 & 2,06 & 11 \\
\hline Jagung & 02 & 1,85 & 12 \\
\hline $\begin{array}{c}\text { Buah- } \\
\text { Buahan }\end{array}$ & 08 & 1,72 & 13 \\
\hline Telur & 26 & 1,67 & 14 \\
\hline $\begin{array}{c}\text { Sayur- } \\
\text { Sayuran }\end{array}$ & 07 & 1,65 & 15 \\
\hline
\end{tabular}

Pendapat dari Amir dan Riphat (2005) bisa dikaitkan dengan hasil Sensus Pertanian Jawa Timur (2014) dan Tabel 9 mengenai sektor pertanian yang tidak termasuk ke dalam tiga besar pengganda tenaga kerja walaupun masih masuk ke dalam lima belas besar, dan bahwa pada sektor pertanian telah terjadi perpindahan tenaga kerja terdidik dari pertanian ke sektor lainnya yang mengakibatkan kontribusi sektor pertanian semakin lemah dan mengalami penurunan produktivitas. Maka, mengakibatkan sumber daya yang tersedia untuk tetap terus melanjutkan sektor pertanian dalam perekonomian adalah rata-rata berpendidikan rendah dan kalah bersaing dengan sektor lainnya, Tidak hanya itu saja keterpaksaan sumber daya manusia yang terbatas membuat sektor pertanian sebagai tujuan utama untuk mencari pekerjaan dan mau menekuni pekerjaan bertani untuk bertahan hidup. Kondisi ini didukung oleh data produktivitas pertanian yang rendah dibandingkan dengan sektor-sektor lainnya dengan nilai sebesar Rp 23,49 juta per tenaga kerja. Hal tersebut berbeda jauh dengan sektor 
industri pengolahan (Rp 108,96 juta), sektor transportasi, pergudangan dan komunikasi ( $\mathrm{Rp}$ 100,06 juta); dan sektor perdagangan, hotel dan restaurant (Rp 87,98 juta).

\section{i. Backward Linkage}

Pada analisis ini, komoditas ternak lainnya; komoditas telur; komoditas domba dan kambing; komoditas susu segar; komoditas unggas lainnya; komoditas ayam; komoditas ikan laut dan hasil perikanan laut memiliki nilai backward linkage lebih dari satu, dapat diartikan sebagai panduan dalam perumusan strategi pembangunan dikarenakan adanya peningkatan permintaan dan menjadi pendorong adanya investasi (produksi) yang lebih baik (Simatupang, 1997 dalam Syafa' at dan Mardianto, 2000).

Pendapat Simatupang (1997) dalam Syafa'at dan Mardianto (2000), didukung oleh Hanani, et, al (2003) dan Soemarno (2003) dalam Dwiastuti, dkk (2008), bahwa setiap komoditas yang dihasilkan di sektor pertanian memiliki kemampuan sebagai bahan baku bagi sektor industri dan juga memiliki nilai yang tinggi dalam keterkaitan sektoral baik keterkaitan ke belakang (backward linkage) dan keterkaitan ke depan (forward linkage).

Tabel 10. Nilai Backward Linkage Sektor Pertanian Jawa Timur Tahun 2013

\begin{tabular}{cccc}
\hline Sektor & Kode & $\begin{array}{c}\text { Nilai } \\
\text { Backward } \\
\text { Linkage }\end{array}$ & Peringkat \\
\hline Telur & 26 & 1,35 & 6 \\
\hline $\begin{array}{c}\text { Domba Dan } \\
\text { Kambing }\end{array}$ & 22 & 1,28 & 7 \\
\hline $\begin{array}{c}\text { Ikan Laut Dan } \\
\text { Hasil Perikanan } \\
\text { Laut }\end{array}$ & 33 & 1,27 & 8 \\
\hline Susu Segar & 25 & 1,16 & 10 \\
\hline Unggas Lainnya & 24 & 1,16 & 11 \\
\hline Ayam & 23 & 1,15 & 12 \\
\hline Tebu & 11 & 0,98 & 15 \\
\hline
\end{tabular}

\section{f. $\quad$ Forward Linkage}

Data pada Tabel 11 menjelaskan bahwa sektor non pertanian menempati urutan ke atas dalam nilai forward linkage yang lebih tinggi dari sektor pertanian. Hal ini dapat menjelaskan bahwa secara keterkaitan ke depan sektor pertanian memiliki keterkaitan yang lemah dengan sektor lainnya. Hal tersebut disebabkan, jika petani mampu menaikkan output dan produktivitas pertanian yang dihasilkan, sektor pertanian mampu memberikan sumbangan bersih untuk industrialisasi daerah (teknologi untuk sektor pertanian).
Tabel 11. Nilai Forward Linkage Sektor Pertanian Jawa Timur Tahun 2013

\begin{tabular}{cccc}
\hline Sektor & Kode & $\begin{array}{c}\text { Nilai } \\
\text { Forward } \\
\text { Linkage }\end{array}$ & Peringkat \\
\hline Padi & 01 & 1,48 & 6 \\
\hline Jagung & 02 & 0,88 & 10 \\
\hline $\begin{array}{c}\text { Ternak } \\
\text { Lainnya }\end{array}$ & 27 & 0,85 & 12 \\
\hline $\begin{array}{c}\text { Jasa Pertanian } \\
\text { Dan }\end{array}$ & 28 & 0,82 & 14 \\
Perkebunan & & & \\
\hline $\begin{array}{c}\text { Domba Dan } \\
\text { Kambing }\end{array}$ & 22 & 0,80 & 15 \\
\hline $\begin{array}{c}\text { Digambarkan } \\
\text { dapat dengan cara } \\
\text { dinaikkan }\end{array}$ & $\begin{array}{c}\text { produksi } \\
\text { dengan }\end{array}$
\end{tabular}
mengalokasikan dana investasi guna perbaikan lahan dan untuk menggunakan teknologi produksi yang lebih baik. Tidak hanya itu saja, produktivitas pertanian yang meningkat pun juga menggambarkan surplus besar yang dapat dipasarkan dan redistribusi pendapatan yang menguntungkan bagi sektor pertanian. Maka, pendapatan petani pun juga bisa meningkat, namun pendapatan per kapita petani yang meningkat diakibatkan kenaikan output pertanian per kapita memunculkan kecenderungan untuk membeli banyak barang-barang manufaktur atau dikarenakan petani masih bersifat kekurangan (kurang makan) membuat penggunaan surplus pertanian tadi untuk pembentukan modal memiliki kesempatan yang kecil dan juga petani mempunyai kecenderungan marginal berkonsumsi tinggi (pertambahan konsumsi yang dilakukan dengan pertambahan pendapatan) (Jhingan, 2012). Oleh sebab itu, pada analisis forward linkage yang bisa dijadikan sebagai komoditas unggulan adalah dari sub sektor tanaman pangan (komoditas padi) dengan nilai 1,48 .

g. Analisis Untuk Menentukan Komoditas Unggulan Di Jawa Timur

Peran sektor pertanian dalam pembangunan ekonomi di Provinsi Jawa Timur didominasi dari sub sektor tanaman pangan, sub sektor peternakan dan hasil lain-lainnya dan sub sektor perikanan.

Maka, melalui pendapat Schultz (1964) dalam Tambunan (2010) yang telah disampaikan di atas dan di tambahkan dengan pendapat Hanani, Ibrahim dan Purnomo (2003), pemerintah harus merencanakan teknologi berbasis lokal. Diartikan bahwa teknologi ini digunakan untuk melakukan penelitian pengembangan teknologi perbaikan potensi 
komoditas. Kegiatan ini dilakukan untuk perbaikan terhadap produktivitas komoditaskomoditas yang ada dan komoditas yang baru sehingga memungkinkan untuk dikembangkan. Hal ini tentunya akan membantu peningkatan produktivitas pertanian, dimana produktivitas pertanian Jawa Timur khususnya terjadi karena kualitas komoditas yang kurang bagus.

Tabel 12. Komoditas Unggulan Sektor Pertanian Provinsi Jawa Timur

\begin{tabular}{clcc}
\hline No & \multicolumn{1}{c}{ Sektor } & Kode & $\begin{array}{c}\text { Rank (Didapat } \\
\text { dari Total Rank } \\
\text { Pada Tabel 5.13 } \\
\text { Dan Diambil } \\
\text { Nilai Rank } \\
\text { Terkecil) }\end{array}$ \\
& & & 137 \\
\hline 1 & $\begin{array}{l}\text { Ikan Laut Dan } \\
\text { Hasil Perikanan } \\
\text { Laut }\end{array}$ & 33 & \\
\hline 2 & Padi & 01 & 149 \\
\hline 3 & Telur & 26 & 155 \\
\hline 4 & Jagung & 02 & 180 \\
\hline 5 & Sapi & 20 & 182 \\
\hline 6 & $\begin{array}{l}\text { Ikan Darat Dan } \\
\text { Hasil Perikanan }\end{array}$ & 32 & 185 \\
& Lainnya & \\
\hline 7 & Sayur-Sayuran & 07 & 188 \\
\hline 8 & Buah-Buahan & 08 & 194 \\
\hline 9 & Ayam & 23 & 196 \\
\hline 10 & Susu Segar & 25 & 196 \\
\hline 11 & Ternak Lainnya & 27 & 197 \\
\hline 12 & $\begin{array}{l}\text { Domba } \\
\text { Kambing Dan }\end{array}$ & 22 & 204 \\
\hline 13 & Kedelai & 03 & 229 \\
\hline 14 & Tebu & 11 & 230 \\
\hline 15 & Tembakau & 12 & 231 \\
\hline & & \\
\hline
\end{tabular}

Penjelasan di atas bila dihubungkan dengan Tabel 12 bahwa komoditas yang menjadi komoditas unggulan di Jawa Timur masih didominasi oleh komoditas dari sub sektor tanaman pangan juga diikuti oleh komoditas dari sub sektor perikanan dan komoditas dari sub sektor peternakan. Komoditas unggul ini diperoleh dari total keseluruhan ranking dari masing-masing analisis yang dilakukan sebelumnya (sektor 1-43). Dilihat dari Tabel 12 yang menjadi komoditas unggulan sektor pertanian diambil 15 sektor terbesar (dilihat dari nilai ranking terkecil): 1). Sub sektor perikanan (komoditas ikan laut dan hasil perikanan lainnya, komoditas ikan darat dan hasil perikanan lainnya); 2), Sub sektor tanaman pangan (komoditas padi, komoditas jagung, komoditas sayur-sayuran, komoditas buah-buahan dan komoditas kedelai); 3) sub sektor peternakan dan hasil lain-lainnya (komoditas telur, komoditas sapi, komoditas ayam, komoditas susu segar, komoditas ternak lainnya, komoditas domba dan kambing) dan 4). Sub sektor perkebunan (komoditas tebu dan komoditas tembakau).

\section{Kesimpulan}

a. Kontribusi sektor pertanian terhadap perekonomian Jawa Timur (disesuaikan dengan pembahasan yaitu lima belas sektor besar) dilihat dari:

Struktur output: output yang dihasilkan oleh sektor pertanian (33 sektor) adalah 183.558.716,28 juta dengan kontribusinya 11, 23 persen. Terdiri dari (nilai terbesar) komoditas padi dengan output terbesar yaitu 38.028.853,89 juta (2,33 persen); ikan darat dan hasil perikanan lainnya yaitu 27.604.611,47 juta (1,69 persen); sapi sebesar 18.704.340,64 juta (1,14 persen).

Struktur nilai tambah bruto yang dihasilkan oleh sektor pertanian (33 sektor) adalah 169.426.431,70 juta dengan kontribusinya 15,88 persen. Terdiri dari (nilai terbesar) komoditas padi dengan nilai tambah bruto terbesar yaitu $40.119 .188,77$ juta (3,76 persen); jagung dan sapi dengan kontribusi sebesar 17.650.798 juta dan 17.604.326,32 juta $(1,65$ persen).

Struktur pendapatan yang dihasilkan oleh sektor pertanian (33 sektor) adalah 50.078.445,51 juta dengan kontribusinya 17,24 persen. Terdiri dari (nilai terbesar) komoditas padi dengan pendapatan terbesar yaitu $12.843 .654,89$ juta (42 persen); sapi dengan kontribusi sebesar 9.319.608,98 juta (3,21 persen); ikan darat dan hasil perikanan lainnya yaitu 4.281.395,49 juta (1,47 persen).

Struktur tenaga kerja (jumlah tenaga kerja) yang dihasilkan oleh sektor pertanian (33 sektor) adalah 36.071 .090 juta orang dengan kontribusinya 25,96 persen. Terdiri dari (nilai terbesar) komoditas ikan darat dan hasil perikanan lainnya yaitu 4.895.134,52 juta orang (3,52 persen); sapi yaitu $3.820 .138,34$ juta orang (2,75 persen); padi sebesar 3.284.693,56 juta orang (2,36 persen).

b. Angka pengganda yang didapatkan dari hasil analisis (disesuaikan dengan pembahasan yaitu lima belas sektor besar) pada: 
Output: angka pengganda yang diciptakan dengan nilai terbesar berada pada terbesar pada komoditas ternak lainnya dengan nilai 2,35 dan terkecil pada komoditas tebu yaitu 1,58.

Pendapatan: angka pengganda yang diciptakan dengan nilai terbesar berada pada komoditas telur dengan nilai 3,51 dan terkecil pada komoditas ikan laut dan hasil perikanan laut dengan nilai 1,89 .

Nilai tambah bruto: angka pengganda yang diciptakan dengan nilai terbesar berada pada komoditas ternak lainnya dengan nilai 2,54 dan terkecil pada komoditas unggas lainnya dengan nilai 1,81 .

Tenaga kerja: angka pengganda yang diciptakan dengan nilai terbesar berada pada komoditas padi dengan nilai 2,12 dan terkecil pada komoditas sayur-sayuran dengan nilai 1,65.

c. Keterkaitan ke belakang (backward linkage) dan keterkaitan ke depan (forward linkage) pada sektor pertanian Jawa Timur (disesuaikan dengan pembahasan yaitu lima belas sektor besar), yaitu:

Keterkaitan ke belakang (backward linkage) yang diciptakan dengan nilai terbesar berada pada komoditas ternak lainnya dengan nilai 1,46 dan terkecil pada komoditas tebu dengan nilai 0,98 .

Keterkaitan ke depan (forward linkage) yang diciptakan dengan nilai terbesar berada pada komoditas padi dengan nilai 1,48 dan terkecil pada komoditas domba dan kambing dengan nilai 0,80 .

Komoditas unggulan sektor pertanian diambil 15 sektor terbesar, yaitu: 1). Sub sektor perikanan (komoditas ikan laut dengan nilai rank 137 dan hasil perikanan lainnya, komoditas ikan darat dan hasil perikanan lainnya dengan nilai rank 185); 2). Sub sektor tanaman pangan (komoditas padi dengan nilai rank 149, komoditas jagung dengan nilai rank 180, komoditas sayur-sayuran dengan nilai rank 188, komoditas buah-buahan dengan nilai rank 194 dan komoditas kedelai dengan nilai rank 229); 3). Sub sektor peternakan dan hasil lain-lainnya (komoditas telur dengan nilai rank 155, komoditas sapi dengan nilai rank 182 , komoditas ayam dengan nilai rank 196, komoditas susu segar dengan nilai rank 196, komoditas ternak lainnya dengan nilai rank 197, komoditas domba dan kambing dengan nilai rank 204) dan 4). Sub sektor perkebunan (komoditas tebu dengan nilai rank 230 dan komoditas tembakau dengan nilai rank 231).

\section{Daftar Pustaka}

Amir, Hidayat dan Riphat, Singgih. 2005. Analisis Sektor Unggulan Untuk Evaluasi Kebijakan Pembangunan Jawa Timur Menggunakan Tabel Input-Output 1994 dan 2000. Jurnal Keuangan dan Moneter, Edisi Desember: 1-25. Departemen Keuangan Republik Indonesia. Jakarta.

Arifin, Bustanul. 2001. Spektrum Kebijakan Pertanian Indonesia. Telaah Struktur, Kasus, dan Alternatif Strategi. Erlangga. Jakarta.

Bappeda Provinsi Jawa Timur. 2013. Pembangunan Ekonomi Provinsi Jawa Timur. Disampaikan dalam: Rapat Koordinasi Pengembangan Kawasan Agropolitan/Minapolitan Tahun 2013. Surabaya.

Dwiastuti, dkk. 2008. Pemetaan ICOR Komoditas Wilayah Untuk Mendukung Kebijakan Revitalisasi Pertanian. Fakultas Pertanian. Universitas Brawijaya. Malang.

Hanani, Nuhfil; Ibrahim, Jabat Tarik dan Purnomo, Mangku. 2003. Strategi Pembangunan Pertanian- Sebuah Pemikiran Baru. Lappera Pustaka Umum. Yogyakarta.

Jhingan, M.L. 2012. Ekonomi Pembangunan Dan Perencanaan. PT. Raja Grafindo Persada. Jakarta.

Sensus Pertanian Jawa Timur. 2014. Analisis Sosial Ekonomi Petani Di Jawa Timur. Analisis Hasil Survei Pendapatan Petani, Sensus Pertanian 2013. Badan Pusat Statistik Provinsis Jawa Timur. Surabaya.

Susilowati, Sri Hery. 2008. Strategi AgriculturalDemand-Led-ndustrialization Dalam Perspektif Peningkatan Kinerja Ekonomi Dan Pendapatan Petani. Forum Penelitian Agro Ekonomi, Vol. XXVI(1): 44-57.

Syafa'at, Nizwar dan Friyatno, Supena. 2000. Analisis Dampak Krisis Ekonomi Terhadap Kesempatan Kerja dan Identifikasi Komoditas Andalan Sektor Pertanian di Wilayah Sulawesi: Pendekatan Input-Output. Ekonomi dan Keuangan Indonesia, Vol: XLVIII(4): 369393. 
Tambunan, Mangara. 2010. Menggagas Perubahan Pendekatan PembangunanMenggerakkan Kekuatan Lokal Dalam Globalisasi Ekonomi. Graha Ilmu. Yogyakarta.

Yulianita, Anna. 2009. Analisis Sektor Unggulan Dan Pengeluaran Pemerintah Di Kabupaten Ogan Komering Ilir. Jurnal Ekonomi Pembangunan: Hal. 70-85. Fakultas Ekonomi. Universitas Sriwijaya. Sumatera Selatan. 